\title{
ANTIBACTERIAL ACTIVITY OF ETHANOLIC EXTRACT OF JAVANESE TURMERIC RHIZOME ENTRAPPTED IN NANOPARTICLES: A NOVEL RULE OF CHITOSAN
}

\author{
SHIRLY KUMALA ${ }^{1}$, DENI RAHMAT ${ }^{*}{ }^{*}$, YUNAHARA FARIDA ${ }^{1}$, BENNY CHANDRA $^{1}$
}

${ }^{1}$ Faculty of Pharmacy, Pancasila University, Srengseng Sawah, Jagakarsa, Jakarta Selatan, 12640, Indonesia Email: denrerum@gmail.com

Received: 16 Jul 2018, Revised and Accepted: 15 Oct 2018

\begin{abstract}
Objective: The aim of this study was to compare the antibacterial activity of $96 \%$ (v/v) ethanolic extract of Javanese turmeric rhizome (Curcuma xanthorrhiza Roxb.) and nanoparticles containing the extract against 4 pathogenic bacteria.

Methods: The synthesis of chitosan nanoparticles used ionic gelation method. The nanoparticles were evaluated for particle size, zeta potential and morphology. Dilution method was performed to determine minimum inhibitory concentration (MIC).

Results: The nanoparticles showed particle size of $53.25 \mathrm{~nm}$, polydispersity index of 0.442 and zeta potential value of +31.5 mv. The antibacterial activity results based on the broth dilution method demonstrated that both the extract and the nanoparticles could inhibit the growth of Staphylococcus aureus, Escherichia coli, Salmonella thypi, and Bacillus subtilis in a concentration of $500 \mu \mathrm{g} / \mathrm{ml}$. The MIC of the extract against Staphylococcus aureus and Bacillus subtilis were $400 \mu \mathrm{g} / \mathrm{ml}$ and against Escherichia coli and Salmonella thypi in a concentration of $500 \mu \mathrm{g} / \mathrm{ml}$. In addition, the MIC of the nanoparticles against Staphylococcus aureus was $300 \mu \mathrm{g} / \mathrm{ml}$ while against Bacillus subtilis and Salmonella thypi $400 \mu \mathrm{g} / \mathrm{ml}$ and against Escherichia coli $500 \mu \mathrm{g} / \mathrm{ml}$.
\end{abstract}

Conclusion: The nanoparticles have a promising strategy to formulate the extracts in order to decrease the MIC against Staphylococcus aureus and Salmonella thypi.

Keywords: Javanese turmeric rhizome, Extract, Nanoparticles, Chitosan, Antibacterial activity

(C) 2018 The Authors. Published by Innovare Academic Sciences Pvt Ltd. This is an open access article under the CC BY license (http://creativecommons.org/licenses/by/4.0/) DOI: http://dx.doi.org/10.22159/ijap.2018v10i6.28521

\section{INTRODUCTION}

Javanese turmeric rhizome (Curcuma xanthorrhiza Roxb.) is one of the many medicinal plants found in Indonesia and has been widely used as jamu to show antidiuretic, anti-inflammatory, antioxidant, antihypertensive, antihepatotoxic, antibacterial, and antifungal effects. It can grow in other areas such as Thailand, Philippines, Sri Lanka, and Malaysia $[1,2]$. The biological activities of $C$. xanthorrhiza are due to some active compounds, including xanthorrhizol and curcumene, and a few volatile compounds. Xanthorrhizol has an important role as antibacterial, antiseptic, and antibiotic [1, 3].

Development of an antibacterial drug based on natural products has been developing because the use of synthetic antibacterial drugs in the long term can give rise many disadvantages effects $[4,5]$. Nanotechnology is a new breakthrough in the field of pharmaceutical technology in which drug particles are prepared with dimensions less than $1000 \mathrm{~nm}$. Thereby, there is a change in the physical properties of active compounds in such a way that it can increase the efficacy of a drug and reduce the doses so as to lower the toxicity of the drug [6].

One of the nanoparticles preparation methods is ionic gelation in which nanoparticles are formed as a result of electrostatic interactions between cationic polymers and anionic crosslinkers. The most commonly used biodegradable polymer is chitosan which is a naturally occuring cationic polymer while sodium tripolyphosphate can serve as a crosslinker [7]. Therefore, it was the aim of this research to investigate both the antibacterial activity of $96 \%(\mathrm{v} / \mathrm{v})$ ethanol extract and its nanoparticles of Javanese turmeric rhizome against Escherichia coli, Salmonella thypi, Staphylococcus aureus, and Bacillus subtilis. The rhizome was extracted by maceration using $96 \%(\mathrm{v} / \mathrm{v})$ ethanol. The extract was then concentrated to get viscous extract which was then solubilized in capric triglyceride (captex), glyceril caprilate (capmul), and ethanol and mixed with chitosan solution to prepare the nanoparticles.

\section{MATERIALS AND METHODS}

\section{Materials}

Javanese turmeric rhizome, ethanol, chitosan, captex, capmul, sodium tripolyphosphate, Escherichia coli ATCC 25922, Staphylococcus aureus ATCC 6538, Bacillus subtilis ATCC 6633, Salmonella typhi ATCC 14028, Mueller-Hinton agar (MHA), MuellerHinton broth (MHB), nutrient agar (NA), potato dextrose agar (PDA), and chloramphenicol. Captex and capmul were purchased from Abitex Corp. (Northampton, UK) and the bacterial strains were obtained from Department of Microbiology, Faculty of Pharmacy, Pancasila University.

\section{Ethanolic extract preparation}

Javanese turmeric rhizome was collected from Lembang Bandung, West Java, Indonesia in October 2017 and identified by The Center for Plant Conservation Botanic Garden-Indonesian Institute of Science with the authentic number is B-112/IPH.3./KS/I/2018. The speciment was deposited by Herbarium of Pharmacognocy Laboratory, Faculty of Pharmacy, Pancasila University (1/DR/HLF/UP). Extract of Javanese turmeric rhizome was prepared by maceration technique using $96 \%(\mathrm{v} / \mathrm{v})$ ethanol. $500 \mathrm{~g}$ of simplisia was macerated with $5 \mathrm{l}$ of $96 \%$ (v/v) ethanol for $24 \mathrm{~h}$ and was then filtered. The residue was re-macerated nine times with the same solvent and evaporated by a rotary evaporator. The resulting viscous extract was identified organoleptically for its color, odor, and taste.

\section{Determination of microbial contamination}

$1 \mathrm{~g}$ of the extract was dissolved in $10 \mathrm{ml}$ of phosphate buffer $\mathrm{pH}$ 7.2). $9 \mathrm{ml}$ of phosphate buffer solution was poured into the test tube from which sixfold serial dilution was made. $1 \mathrm{ml}$ of each dilution was inoculated in the petri dishes. $20 \mathrm{ml}$ each of NA medium (liquid) and PDA medium (liquid) were used for total count plate (TCP) and total yeast mold count (TYMC), respectively. After solidification of each medium plates were incubated upside down at $37^{\circ} \mathrm{C}$ for NA medium for $2 \mathrm{~d}$ and at $25{ }^{\circ} \mathrm{C}$ for PDA medium for $7 \mathrm{~d}$. The growing 
colonies were counted, recorded and the colony of forming units (CFU) of the extract was calculated [8-11].

\section{Nanoparticles preparation by ionic gelation}

Ionic gelation method was performed to obtain the nanoparticles. Briefly, $1 \mathrm{~g}$ of the extract was dissolved in various concentrations of capmul, captex, and $70 \%(\mathrm{v} / \mathrm{v})$ ethanol using a magnetic stirrer. $1 \%$ (w/v) chitosan solution was added to the mixture and mixed until homogeneous. Afterwards, $10 \mathrm{ml}$ of $0.4 \%$ (v/v) sodium tripolyphosphate solution was added dropwise to the final mixture under a magnetic stirring of $400 \mathrm{rpm}$ at room temperature. Distilled water was added to reach the extract concentration of $1 \%(\mathrm{w} / \mathrm{v})$. The suspension was then evaluated for its particle size, zeta potential and morphology.

Determination of inhibitory zone of the extract and the nanoparticles

All the test strains obtained from Department of Microbiology, Faculty of Pharmacy, Pancasila University were sub-cultured on MHA medium, incubated at $37^{\circ} \mathrm{C}$ for $24 \mathrm{~h}$ and stored at $4{ }^{\circ} \mathrm{C}$ in the refrigerator to maintain stock culture. Sterile filter paper was used to prepare $6 \mathrm{~mm}$ in diameter discs and $10 \mu \mathrm{l}$ of the extract and the nanoparticles were impregnated on the disc. The determination was performed three times for each of the test bacteria. After incubation, the plates were observed for the presence of the clear zone and the diameters for each bacteria were measured in $\mathrm{mm}$. A clear inhibition zone around impregnated disc was the indication of the presence of antibacterial activity.

The antibacterial activity of the extract and the nanoparticles were performed against test bacteria namely Staphylococcus aureus, Escherichia coli, Salmonella thypi, and Bacillus subtilis. $0.1 \mathrm{ml}$ of bacterial suspension $\left(10^{7} \mathrm{CFU}\right)$ was put into a petri dish then $15 \mathrm{ml}$ of nutrient agar as a medium was poured, homogenized and allowed to solidify for $15 \mathrm{~min}$. The extract was solubilized and the dried nanoparticles were suspended in sterilized water to obtain concentrations of 500, 250, and $125 \mu \mathrm{g} / \mathrm{ml}$. The disc papers impregnated with the extract solutions or the nanoparticles suspensions were put on the surface of the solid medium in the petri dishes and incubated at $37^{\circ} \mathrm{C}$ for $24 \mathrm{~h}$. Chloramphenicol solution was served as control [12-14].
Determination of minimum inhibitory concentration (MIC) of the extract and the nanoparticles

MIC of the extract and the nanoparticles were determined by the dilution method using MHB medium. The bacterial suspension was made from an overnight culture and diluted to a turbidity comparable to that of a $0.5 \mathrm{McF}$ arland standard and further diluted with broth so that the final concentration of the bacteria was approximately $10^{6} \mathrm{CFU} / \mathrm{ml}$. The tube was filled with a two-fold dilution of the extract stock solution or the nanoparticles suspension mixed with each the test bacteria in MHB medium. The purpose of the two-fold dilution is to reduce the concentration of the solution by a factor of two, which then reduces the original concentration by one half.

For each of the tested bacteria, $1 \mathrm{ml}$ of the extract solution or the nanoparticles suspension at various concentrations were poured into 12 test tubes ( 6 tubes for the extract and 6 tubes for the nanoparticles) containing $9 \mathrm{ml}$ of peptone broth. $0.1 \mathrm{ml}$ of bacterial inoculum was added into the mixture in each tube and incubated at $37^{\circ} \mathrm{C}$ for $24 \mathrm{~h}$. The mixture of fresh medium and inoculum served as the positive control. The MIC is defined as the lowest concentration of an antimicrobial agent that prevents visible growth of test bacterias in the test tubes. The tube with no visible growth after the incubation was perceived as the MIC [12-14].

\section{Statistical analysis}

All experiments were carried out in triplicates. Data obtained were analyzed by one-way analysis of variance (ANOVA). Differences were considered significant at $\mathrm{p}<0.05$.

\section{RESULTS AND DISCUSSION}

\section{Ethanolic extract preparation}

The viscous extract obtained was evaluated organoleptically to investigate the specific identity of the extract as shown in table 1 . The weight of the viscous extract was $135.2 \mathrm{~g}$ which was obatained from $500.5 \mathrm{~g}$ of the simplisia powder for the maceration. Nine times remaceration made the maceration exhausted, resulting in a comparatively high rendement.

Table 1: Organoleptic evaluation of extract of Javanese turmeric rhizome

\begin{tabular}{ll}
\hline Parameter & Characteristic \\
\hline Viscosity & Viscous \\
Color & Yellowish brown \\
Odor & Specific odor of the rhizome \\
Taste & Bitter \\
\hline
\end{tabular}

\section{Determination of microbial contamination}

The viscous extract obtained was evaluated for its microbial contamination including determination of TPC and TYMC. Microbial contaminations were performed to find out the amount of bacteria, yeast and mold present in the extract. The growing colonies will affect the antibacterial activity of the extract. Normally, the number of colonies of TPC ranges between 30 to 300 colonies, whereas the highest number colonies for TYMC is less than 50 . Based on the results of microbial contamination as shown in table 2 and 3, the extract contained only a few colonies that were considered as too few to count (TFC). The extract possesses some active compounds which can act as an antibacterial agent, thus only a few amount of microbes are able to survive in the extract [15-17].

Table 2: TPC of extract of javanese turmeric rhizome

\begin{tabular}{lllllll}
\hline Sample & \multicolumn{2}{l}{ Colonies of dilution } & & & \\
\cline { 2 - 6 } & $\mathbf{1 0}^{-1}$ & $\mathbf{1 0}^{-\mathbf{2}}$ & $\mathbf{1 0}^{-3}$ & $\mathbf{1 0}^{-\mathbf{4}}$ & $\mathbf{1 0}^{-\mathbf{5}}$ & $\mathbf{1 0}^{-\mathbf{6}}$ \\
\hline I & $<30$ & $<30$ & $<30$ & $<30$ & $<30$ & $<30$ \\
II & $<30$ & $<30$ & $<30$ & $<30$ & $<30$ & $<30$ \\
\hline
\end{tabular}

Notes: <: Less than

Table 3: TYMC of extract of Javanese turmeric rhizome

\begin{tabular}{|c|c|c|c|c|c|c|}
\hline \multirow[t]{2}{*}{ Sample } & \multicolumn{6}{|c|}{ Colonies of dilution } \\
\hline & $10^{-1}$ & $10^{-2}$ & $10^{-3}$ & $10^{-4}$ & $10^{-5}$ & $10^{-6}$ \\
\hline I & $<10$ & $<10$ & $<10$ & $<10$ & $<10$ & $<10$ \\
\hline II & $<10$ & $<10$ & $<10$ & $<10$ & $<10$ & $<10$ \\
\hline
\end{tabular}

Notes: <: Less than 


\section{Nanoparticles preparation by ionic gelation}

The preparation of nanoparticles was carried out by the ionic gelation method, in which nanoparticles are formed as a result of electrostatic interaction of positively charges of functional groups of chitosan with negatively charges of sodium tripolyphosphate [18]. The ionic gelation method enables the synthesis of nanoparticles in a simple way without the use of heat and high pressure so as to ensure the stability of the active substances during the process of generating nanoparticles. The solvents used to dissolve the extract were captex, capmul, ethanol $70 \%(\mathrm{v} / \mathrm{v})$, and chitosan. The optimal formula used is shown in table 4. Generally, captex and capmul are used for the formulation of nanoemulsion and microemulsion [19, 20]. It is beneficial to mix both components in proper ratio as oily phase was exist in the extract. Furthermore, the extract was more soluble in the presence of $70 \%(\mathrm{v} / \mathrm{v})$ ethanol, but the oily phase separated out of the mixture. The addition of $1 \%(\mathrm{w} / \mathrm{v})$ of chitosan made the final mixture stable and homogeneous. This phenomena demonstrated that chitosan is not only as a carrier but also as a stabilizer in the emulsification. This could be a novel rule and properties of chitosan. This system was further stabilized by the addition of sodium tripolyphosphate as a crosslinker. Obiviously, the nanoparticles system combines two technology namely microemulsion and ionic gelation. Moreover, the presence of chitosan in the system is necessary to render mucoadhesive and permeation enhancing properties [21]. This kind of nanoparticles did not leave any stain from curcumin after the application on the human skin.

Table 4: The optimal formula of nanoparticles

\begin{tabular}{ll}
\hline Ingredient & Quantity \\
\hline Extract of Javanese turmeric rhizome & $1 \mathrm{~g}$ \\
Captex & $15 \mathrm{ml}$ \\
Capmul & $15 \mathrm{ml}$ \\
Ethanol 70\% (v/v) & $25 \mathrm{ml}$ \\
Chitosan 1\% (w/v) & $20 \mathrm{ml}$ \\
Sodium tripolyphosphate $0.4 \%$ & $10 \mathrm{ml}$ \\
Distilled water & to $100 \mathrm{ml}$ \\
\hline
\end{tabular}

The preparation of nanoparticles which used the optimum formula resulted in a homogeneous dispersion of nanoparticles. The stability of nanoparticles suspension was observed for $5 \mathrm{~d}$ in regard to parameters such as color, turbidity, and sedimentation. Based on the observations, the change in color and turbidity did not occur and the sediment was not found on the bottom of the container. The stable nanoparticles suspension was characterized for particle size, zeta potential and morphology. Particle size of the nanoparticles was $53.25 \mathrm{~nm}$. The polydispersity index showed the homogeneity of the particle size. The polydispersity index of the nanoparticles was 0.442 thus the nanoparticles displayed a comparatively good degree of homogeneity. In addition, zeta potential of the nanoparticles was $+31.5 \mathrm{mV}$. The use of chitosan as a cationic polymer may affect the value of zeta potential.

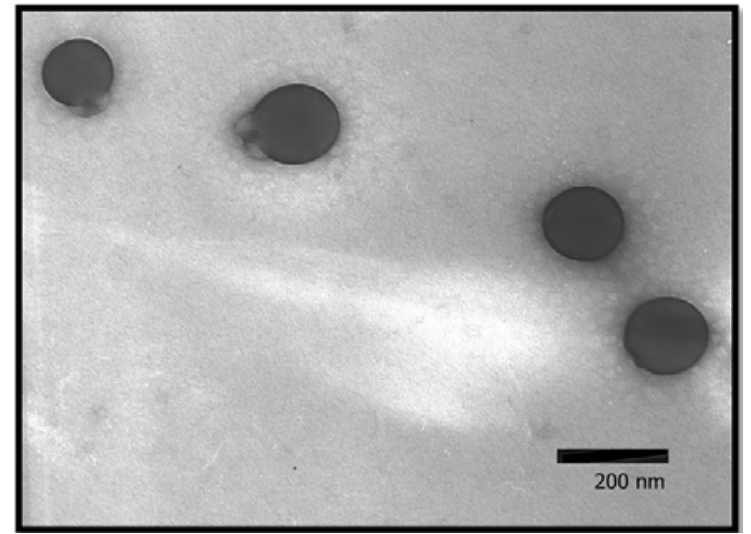

Fig. 1: Transmision electron microscopy of nanoparticles containing $95 \%(\mathrm{v} / \mathrm{v})$ ethanolic extract of Javanese turmeric rhizome

\section{Determination of inhibitory zone of the extract and the nanoparticles}

Based on the result of determination of inhibition diameter of the extract, it was found that both the extract and the nanoparticles in a concentration of $500 \mu \mathrm{g} / \mathrm{ml}$ were able to inhibit the growth of the test bacteria as shown in table 5 and 6 . In addition, the nanoparticles were able to inhibit the growth of all test bacteria in a smaller diameter compared to the extract. The slow release of the active compounds from the nanoparticles probably gives rise the low antibacterial activity. The MIC of the extract and the nanoparticles are shown in table 7 and 8 , respectively. Surprisingly, the nanoparticles were more sensitive to inhibit the growth of Staphylococcus aureus and Salmonella thypi as demonstrated by the lower MIC against the corresponding bacteria.

Table 5: Clear zone of ethanolic extract of Javanese turmeric rhizome

\begin{tabular}{|c|c|c|c|c|}
\hline \multirow{2}{*}{$\begin{array}{l}\text { Concentration } \\
(\mu \mathrm{g} / \mathrm{ml})\end{array}$} & \multicolumn{4}{|c|}{ Clear zone diameter $(\mathrm{mm})^{*}$} \\
\hline & Staphylococcus aureus & Escherichia coli & Salmonella thypi & Bacillus subtilis \\
\hline 500 & $10.22 \pm 1.19$ & $11.24 \pm 4.39$ & $19.05 \pm 0.84$ & $8.96 \pm 2.30$ \\
\hline 250 & - & - & - & - \\
\hline 125 & - & - & - & - \\
\hline Ethanol $96 \%(v / v)$ & - & - & $6.39 \pm 0.19$ & - \\
\hline 30 (Chloramphenicol) & $24.65 \pm 1.41$ & $21.25 \pm 0.09$ & $21.15 \pm 1.26$ & $20.38 \pm 0.54$ \\
\hline
\end{tabular}

Notes: Data are given in mean \pm SD, $n=3$, SD: Standard deviation 
Table 6: Clear zone of nanoparticles of ethanolic extract of Javanese turmeric rhizome

\begin{tabular}{|c|c|c|c|c|}
\hline \multirow{2}{*}{$\begin{array}{l}\text { Concentration } \\
(\mu \mathrm{g} / \mathrm{ml})\end{array}$} & \multicolumn{4}{|c|}{ Clear zone diameter (mm)* } \\
\hline & Staphylococcus aureus & Escherichia coli & Salmonella thypi & Bacillus subtilis \\
\hline 500 & $6.22 \pm 0.03$ & $6.81 \pm 0.54$ & $7.37 \pm 0.33$ & $8.96 \pm 2.30$ \\
\hline 250 & - & - & - & - \\
\hline 125 & - & - & - & - \\
\hline Sterile aquadest & - & - & - & - \\
\hline 30 (Chloramphenicol) & $24.65 \pm 1.41$ & $21.25 \pm 0.09$ & $21.15 \pm 1.26$ & $20.38 \pm 0.54$ \\
\hline
\end{tabular}

Notes: Data are given in mean $\pm S D, n=3$, SD: Standard deviation

The aim of broth dilution methods is to determine the lowest concentration of the extract and the nanoparticles (MIC) that are able to inhibit the visible growth of the test bacteria being studied.
MIC values are used to determine susceptibilities of bacteria to the active compounds of the extract and also to evaluate the activity of the nanoparticles containing the extract.

Table 7: MIC of ethanolic extract of Javanese turmeric rhizome

\begin{tabular}{|c|c|c|c|c|}
\hline \multirow{2}{*}{$\begin{array}{l}\text { Concentration } \\
(\mu \mathrm{g} / \mathrm{ml})\end{array}$} & \multicolumn{4}{|l|}{ Type of bacteria } \\
\hline & Staphylococcus aureus & Escherichia coli & Salmonella thypi & Bacillus subtilis \\
\hline 500 & - & - & - & - \\
\hline 400 & - & + & + & - \\
\hline 300 & + & + & + & + \\
\hline 200 & + & + & + & + \\
\hline 100 & + & + & + & + \\
\hline 50 & + & + & + & + \\
\hline
\end{tabular}

Notes: -: Clear,+: Turbid

Table 8: MIC of nanoparticles containing Javanese turmeric rhizome

\begin{tabular}{|c|c|c|c|c|}
\hline \multirow{2}{*}{$\begin{array}{l}\text { Concentration } \\
(\mu \mathrm{g} / \mathrm{ml})\end{array}$} & \multicolumn{4}{|l|}{ Type of bacteria } \\
\hline & Staphylococcus aureus & Escherichia coli & Salmonella thypi & Bacillus subtilis \\
\hline 500 & - & - & - & - \\
\hline 400 & - & + & - & - \\
\hline 300 & - & + & + & + \\
\hline 200 & + & + & + & + \\
\hline 100 & + & + & + & + \\
\hline 50 & + & + & + & + \\
\hline
\end{tabular}

Notes: -: Clear,+: Turbid

The nanoparticles could show an antibacterial activity against both Gram-positive and Gram-negative bacteria. Gram-negative bacteria have a double membrane to defend against extract interference. The hydrophilic cell wall structure of Gram-negative bacteria is able to block the permeation of antibacterial compounds [22, 23]. Based on the the MIC results, since the nanoparticles have an importanat role in the permeation enhancing properties it demonstrated that the nanoparticles could lower the MIC of the extract.

\section{CONCLUSION}

Nanoparticles containing $96 \%$ (v/v) ethanolic extract of Javanese turmeric rhizome were prepared by microemulsion and ionic gelation method using chitosan and sodium tripolyphosphate. In addition, chitosan can stabilize the system of microemulsion. Both the extract and the nanoparticles demonstrated antibacterial activity against all test bacteria. Therefore, the nanoparticles are a promising strategy to deliver the active compounds of the extract.

\section{ACKNOWLEDMENT}

The authors gratefully acknowledge financial support from Ristek DIKTI Indonesia (Penelitian Dasar Unggulan Perguruan Tinggi).

\section{AUTHORS CONTRIBUTIONS}

All the author have contributed equally

\section{CONFLICT OF INTERESTS}

The author reports no declarations of interest

\section{REFERENCES}

1. Salleh NAM, Ismail S, Halim MRA. Effects of Curcuma xanthorrhiza extracts and their constituents on phase ii drug metabolizing enzymes activity. Pharmacogn Res 2016;8:309-15.

2. Oon SF, Nallappan M, Tee TT, Shohaini S, Kassim NK, Sa'ariwijaya MSF, et al. Xanthorrhizol: a review of its pharmacological activities and anticancer properties. Cancer Cell Int 2015;15:2-15.

3. Jayaprakasha GK, Rao LJM, Sakariah KK. Chemistry and biological activities of C. longa. Trends Food Sci Technol 2005;16:533-48.

4. Fair RJ, Tor Y. Antibiotics and bacterial resistance in the $21^{\text {st }}$ century. Perspect Med Chem 2014;6:25-64.

5. Rai J, Randhawa GK, Kaur M. Recent advances in antibacterial drugs. Int J Appl Basic Med Res 2013;3:3-10.

6. Jabir NR, Tabrez S, Ashraf GM, Shakil S, Damanhouri GA, Kamal MA. Nanotechnology-based approaches in anticancer research. Int J Nanomed 2012;7:4391-408.

7. Al-nemrawi NK, Alsharif SSM, Dave RH. Preparation of chitosan-TPP nanoparticles: the influence of chitosan polymeric properties and formulation variables. Int J Appl Pharm 2018;10:60-5.

8. Wilson SC, Holder WH, Easterwood KV, Hubbard G, Johnson $\mathrm{RH}$, Cooley JD, et al. Identification, remediation, and monitoring processes used in a mold-contaminated high school. Adv Appl Microbiol 2004;55:409-23.

9. Smith CF, Townsend DE. A new medium for determining the total plate count in food. J Food Prot 1999;62:1404-10. 
10. Paulsen P, Schopf E, Smulders FJM. Enumeration of total aerobic bacteria and Escherichia coli in minced meat and on carcass surface samples with an automated most probablenumber method compared with colony count protocols. J Food Prot 2006;69:2500-3.

11. Abid H, Ali J, Waqas M, Anwar Y, Ullah J. Microbial quality assessment study of branded and unbranded milk sold in Peshawar city, Pakistan. Pakistan J Nutr 2009;8:704-9.

12. Balouiri M, Sadiki M, Ibnsouda SK. Methods for in vitro evaluating antimicrobial activity: a review. J Pharm Anal 2016;6:71-9.

13. Arullappan S, Zakaria Z, Basri DF. Preliminary screening of antibacterial activity using crude extracts of Hibiscus rosa sinensis. Trop Life Sci Res 2009;20:109-18.

14. Bhalodia NR, Shukla VJ. Antibacterial and antifungal activities from leaf extracts of Cassia fistula l.: an ethnomedicinal plant. J Adv Pharm Technol Res 2011;2:104-9.

15. United States Pharmacopeia; 2011. Rockville: United States Pharmacopeial Comvention; 2010. p. 50-2.

16. Salzman MB, Isenberg HD, Rubin LG. Use of disinfectants to reduce microbial contamination of hubs of vascular catheters. J Clin Microbiol 1993;31:475-9.

17. Corkidi G, Diaz-Uribe R, Folch-Mallol JL, Nieto-Sotelo J. Covasiam: an image analysis method that allows detection of confluent microbial colonies and colonies of various sizes for automated counting. Appl Environ Microbiol 1998;64:1400-4.

18. Wenjing Y, Jing F, Ting W, Nongyue H. Chitosan/sodium tripolyphosphate nanoparticles: preparation, characterization and application as drug carrier. J Biomed Nanotechnol 2009;5:591-5

19. Singh B, Bandopadhyay S, Kapil R, Singh R, Katare OP. Selfemulsifying drug delivery systems (sedds): formulation development, characterization, and applications. Crit Rev Ther Drug Carrier Syst 2009;26:427-521.

20. Niederquell A, Kuentz M. Proposal of stability categories for nano-dispersions obtained from pharmaceutical selfemulsifying formulations. Int J Pharm 2013;446:70-80.

21. Abouhussein DMN, El-Bary AA, Shalaby SH, El Nabarawi MA. Chitosan mucoadhesive buccal films: effect of different casting solvents on their physicochemical properties. Int J Pharm Pharm Sci 2016;8:206-13.

22. Sylvester WS, Son R, Lew KF, Rukayadi Y. Antibacterial activity of Java turmeric (Curcuma xanthorrhiza Roxb.) extract against Klebsiella pneumoniae isolated from several vegetables. Int Food Res I 2015;22:1770-6.

23. Mishra N, Behal KK. Antimicrobial activity of some spices against selected microbes. Int J Pharm Pharm Sci 2010;2:18796. 